\title{
Detection of Animal Fat Mixtures in Meatballs Using Fourier Transform Infrared Spectroscopy (FTIR Spectroscopy)
}

\author{
Imelda Fajriati $^{1 *}$, Yusi Rosadi ${ }^{2}$, Nisrina Nabila Rosadi ${ }^{3}$, Khamidinal $^{4}$ \\ ${ }^{1,2,3}$ Department of Chemistry, Faculty of Science and Technology UIN Sunan Kalijaga, Depok, \\ Yogyakarta 55283, Indonesia \\ ${ }^{4}$ LPPOM MUI DIY, Umbulharjo Yogyakarta 55166, Indonesia \\ e-mail: imelda.fajriati@uin-suka.ac.id*1, yusirosadi08@gmail.com² ${ }^{2}$ rosyidinabila@gmail.com ${ }^{3}$, \\ khami_06@yahoo.com ${ }^{4}$
}

*Corresponding Author

Received: January 28, 2021; Accepted: February 24, 2021

\begin{abstract}
Detection of animal mixtures in meatballs by using Fourier Transform Infrared Spectroscopy (FTIR spectroscopy) has been studied. This research aims to study the different markers of fat characters in meatballs containing the mixture of chicken fat, lard and rat fat. Sample preparation used Soxhlet extraction with $n$-hexane solvent and distillation of fat from the solvent. The extraction temperature is $70^{\circ} \mathrm{C}$ with solvent volume $200 \mathrm{~mL}$. Fat samples were prepared by varying the ratio of 100\% chicken fat concentration which corresponds to 1\%, $10 \%$, and $20 \%$ lard, and 1\%, 10\%, and 20\% rat fat. The meatballs were made with a composition of $0 \%, 5 \%$ and $90 \%$ rat meat. The result of FTIR interpretation shows that the increasing concentration of the mixture of lard and rat fat have increased the absorption at wave numbers of $3371 \mathrm{~cm}^{-1}, 3332 \mathrm{~cm}^{-1}, 2337 \mathrm{~cm}^{-1}$, and 1743 $\mathrm{cm}^{-1}$. The FTIR spectrum is interpreted based on the uptake of typical functional groups of animal fats. The characteristics of animal fat properties can be distinguished by consistent results using infrared spectroscopy.
\end{abstract}

Keywords: chicken fat, FTIR spectroscopy, lard, rat fat.

\section{Introduction}

Halal status of a product is still a crucial issue because it involves sharia law that must be followed by Muslims. One of the status of halal food products concern in food that contains animal fat. The existence of animal fats in small amounts is a problem. It is because there is the difficulty in identifying the content in these food products (Rohman et al., 2020). The physicochemical properties of animal fats have different and distinctive characters, although the physical differences are not significant. This difference is influenced by several factors, including age and species, type of feed, position or location of fat tissue, and the method of processing meat (Hasanah, 2015).

Islam forbids to consume rats because they are haram animals, as supported in the hadith narrated by Bukhari: 3314 and Muslim: 67 below: "There are five kinds of fasiq (dangerous, evil, and disturbing) animals that can be killed either in or outside the land of harom (being ihram or not), namely: snakes, crows, rats, fierce dogs, and eagles".

The technique for detecting the presence of prohibition substances such as rats' lard and lard are to determine the chemical effects of fats in meatball samples. One method that has been developed for the analysis of fats in food can use FTIR spectroscopy. This technique is to identify the molecular structure of the compound and to produce the unique spectrum both of main absorption area $\left(1500 \mathrm{~cm}^{-1}\right.$ to $\left.4000 \mathrm{~cm}^{-1}\right)$ and the fingerprint area $\left(400 \mathrm{~cm}^{-1}\right.$ to $\left.1500 \mathrm{~cm}^{-1}\right)$. The FTIR method is reported quite consistent in identifying the typical characters in animal fats. It is simple and inexpensive method (Jaswir et al., 2003; Rahmania et al., 2015).

Meatballs are one of the most popular and easily processed food products in Indonesia. Meatballs can be made from basic ingredients of chicken or beef. The use of animal meat can increase the production costs because the price of both chicken and beef are relatively expensive. The sellers can use adulterated meat from banned animal meat like rat meat. The purpose of it is to reduce the production costs. The research that had been conducted by Rahmania et al. (2014) and Guntarti \& Prativi (2017) reported that there are rat meat contamination in several meatballs circulating in Yogyakarta. However, these studies have not reported the characteristics of animal fat mixtures such as chicken fat, lard and rat fat. This study reported the identification of animal fat in a mixture of 
chicken fat, lard and rat fat in meatballs. This study was conducted in the different composition of fat content that has not been reported in the previous studies.

The meatball samples were three types of meatballs which were hand-made that consists of rat fat, rat fat meatball samples, and the mix from both of them. The sample preparation both from standard fat and meatball fat samples by using Soxhlet extraction. It is the method of separating one or more than one materials from solid or liquid with the solvent boost. (Bernascone et al., 1995). The solvent used in separating chicken fat, rat fat, and n-hexane solvent lard. Prabawati \& Fajriati (2017) reported that $\mathrm{n}$-hexane solvent had been used in liquid solid extraction process for the analysis of beef and lard. The result of the analysis showed several profiles of IR absorption bands from the mixture of chicken fat, rat fat and lard, both in pure fat and the meatball mixture.

\section{Materials and Methods}

2.1. Materials and Apparatus

The materials were Adipose tissues of chicken, pork and fat, anhydrous $\mathrm{Na}_{2} \mathrm{SO}_{4}$, alcohol $\left(\mathrm{C}_{2} \mathrm{H}_{5} \mathrm{OH}\right)$, n-hexane $\left(\mathrm{C}_{6} \mathrm{H}_{14}\right)$ extraction solvent. The apparatus are FTIR spectrophotometer (IR, Shimadzu Prestige-21), a set of liquid solid extraction equipment, distillation device, desicator, hot plate stirrer (Cimarec Brand), fume hood (ESCO Frontier), heating mantle (Heating thermometer) and oven (Ohaus).

\subsection{Standard Fat Sample Preparation by Soxhlet Extraction}

25 grams of chicken fat, lard, and rat fat were weighed. Furthermore, the sample is wrapped in filter paper and inserted into the sleeve of the liquid solid extraction tool. Then the temperature mantle is heated of $70^{\circ} \mathrm{C} .200 \mathrm{~mL}$ of $\mathrm{n}$-hexane was added then it was extracted for two hours. The use of nhexane volume and extraction time is based on the previous research (Prabawati \& Fajriati, 2017).

The extraction results were added with anhydrous $\mathrm{Na}_{2} \mathrm{SO}_{4}$ and distilled. The result of the distillation is in the oven at $105^{\circ} \mathrm{C}$ and cooled in a desiccator. The fat has made the mixture of the composition of $100 \%$ and lard or rat fat were taken as much as $1 \%, 10 \%$, and $20 \%$. Then the fat was mixed and analyzed by using FTIR Spectroscopy.

In the same way the fat was carried out for meatball samples using n-hexane solvent. The mantle temperature is $70^{\circ} \mathrm{C}$ with an extraction time of two hours. The samples were obtained from hand-made meatballs by using tapioca flour and seasonings. The first meatball only contains chicken fat. While the second meatball used rat fat. Then the third meatball used the lard.

\subsection{Detection by FTIR Spectroscopy}

The number of the volumes of fat extract in the sample holder measured FTIR absorbance at a wave was at number $400-4000 \mathrm{~cm}$. The sample consists of the mixture of $100 \%$ chicken fat and $1 \%$, $10 \%$, and $20 \%$ from lard and $1 \%, 10 \%$, and $20 \%$ from rat fat were analyzed using FTIR Spectrometer (Shimadzu Prestige-21). The absorbance spectra indicated that the character of each animal fat in the sample mixture.

\section{Results and Discussion}

\subsection{Sample Preparation}

An animal fat sample was prepared in two types. They are standard animal fat and animal fat in meatballs. The standard animal fat is derived from the part of the animal's body that contains lots of fat such as the neck and stomach. While the fat in the meatball sample was obtained from three types of meatballs which were made by adding a certain amount of animal fat. The use of three meatball samples in testing the consistency of the instrument and in detecting contamination of the mixture of animal fats. The animal fat samples were taken from chicken fat, lard and rat fat. The separation of fat samples used the Soxhlet extraction technique at $70^{\circ} \mathrm{C}$ by using $\mathrm{n}$-hexane solvent.

According to Hidayat et al. (2013) that the boiling point of the solvent greatly affects the yield of the extraction, because it is the accuracy of the maximum evaporation limit of $n$-hexane solvent. The extract and the solvent are separated by evaporation with the boiling point is not too close. The difference in yield is caused by several factors, including age and species, type of feed, position or location of fat tissue, and the way of processing the food (Bustan et al., 2008).

The extraction yield will increase with increasing amounts of solvent used to a certain extent where the yield increase is relatively small and tends to be constant. Chicken fat samples tended to produce higher yields than samples of lard and rat fat. This is due to the characteristics of lard which is denser so that the ease of dissolving in the solvent is relatively difficult. The rat fat was due to the 
amount of bulk rat fat which was difficult to obtain. The characteristics of these fats relate to the composition of the fatty acids in these fats.

\subsection{Characterization of Chicken Fat, Lard, and Rat Fat Standards Using FTIR Spectroscopy}

FTIR spectroscopic analysis is based on the characterization of functional groups in chicken fat, lard, and rat fat. The Standard fat spectra profiles of chickens fats, lard and rat fat are shown in Figure 1. The Figure 1 shows that the rat fat has a broad and strong absorption. This indicates that the presence of $\mathrm{OH}$ groups from $\mathrm{O}-\mathrm{H}$ bonds (aliphatic or aromatic) as typical of fatty acid absorption are dominant. The rat fat spectra profile is according to fatty acids in rat. The content fatty acid in rat are C12: 0, C16: 0, C16: 1 cis 9, and C18:0 which is higher than beef fat and lard. The specific animal fat interpretative markers can be obtained through the area fingerprint absorption profile. Pebriana et al. (2017) reported that the area of wave number $750-1800 \mathrm{~cm}^{-1}$ is typical for rat fat. PCA and PLS modeling is needed to identify and confirm the distinctive uptake of rat fat.

The spectrum that indicates the difference in animal fat absorption is also located at the wave number $1700 \mathrm{~cm}^{-1}$, which is the stretching absorption of the $\mathrm{C}=\mathrm{O}$ group. The absorption characteristics of this wave number are in accordance with those reported by Buana \& Fajriati (2019) and Prabawati \& Fajriati (2017). FTIR analysis was carried out in mixed fat composition to determine the animal fat uptake of chicken, rat and pork (Figure $2 \& 3$ ).

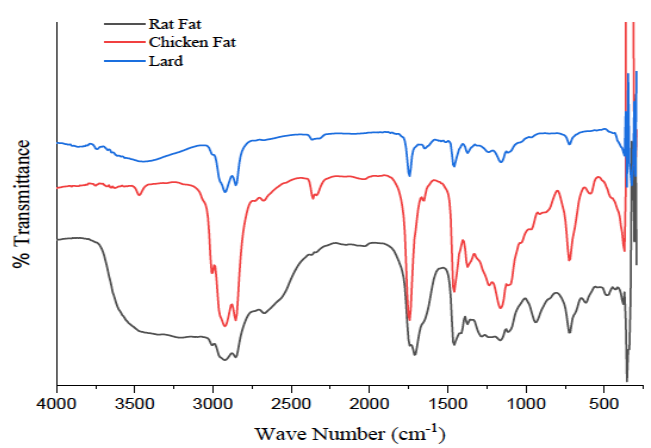

Figure 1. Spectra profile of standard chicken fat, lard, and rat fat.

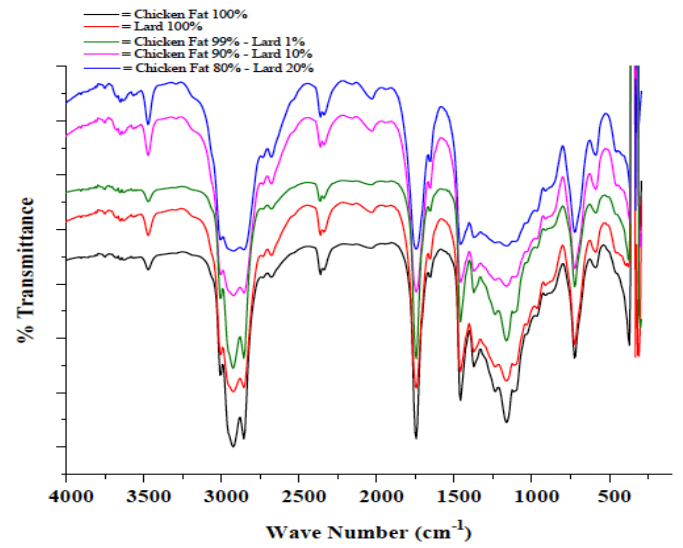

Figure 2. FTIR Spectra Profile of a mixture of chicken fat and lard with different compositions

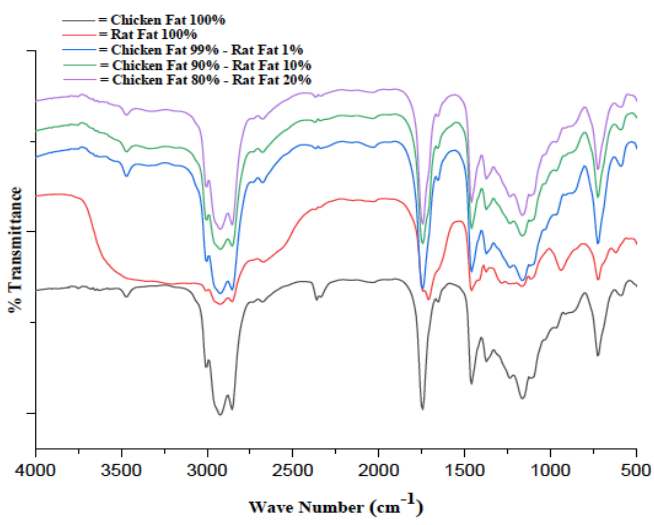

Figure 3. FTIR Spectra Profile of a mixture of chicken fat and rat fat with different compositions 
It can be seen that the difference in intensity at wave numbers $2924 \mathrm{~cm}^{-1}$ and $2854 \mathrm{~cm}^{-1}$ is the characteristic of methylene $\left(-\mathrm{CH}_{2}-\right)$ and methyl $\left(-\mathrm{CH}_{3}\right)$ stretching vibration where the intensity of rat fat absorption is wider than lard and chicken fat (Figure $2 \& 3$ ). At wave numbers $1651 \mathrm{~cm}^{-1}$ and 1658 $\mathrm{cm}^{-1}$, the absorption band of rat fat is lower than mixture of chicken fat and lard. The difference is also found in the wave number $1118-1111 \mathrm{~cm}^{-1}$ which indicates that the presence of the bending $\mathrm{C}-\mathrm{H}$ group with higher intensity of chicken fat.

The difference in absorption characteristic is according to the content of saturated and unsaturated fatty acids in animal fats. As reported by Utami (2017) that rat fat contains fatty acids of 9-Octadecenoic acid, Hexadecanoic acid, and Methyl arachidonate which is more extra than chicken fat, lard and beef fat. The main composition of fatty acids has the main chain of C17 and C19 in rat fat that is very dominant. This is confirmed by the research of Jaswir et al. (2003) which stated that overlapping in the two wave number regions showed that there were the differences between the content of saturated fatty acids and unsaturated fatty acids of each sample.

The difference in absorption bands in chicken fat and lard is also due to the composition of fatty acids or fatty acids types that contained the different triglycerides. When the composition of fatty acids can determine the physical and chemical properties of fat or oil. It is known that there are the longer fatty acid carbon chain and the higher unsaturation level. According to Vacawati et al. (2013) stated that lard had higher absorption band than chicken fat in the $3400 \mathrm{~cm}^{-1}$ area due to the content of unsaturated fatty acids, especially in linoleic acid.

\subsection{Characterization of Mixed Meatball Samples for Chicken Fat, Lard, and Rat Fat}

The spectral profile of fats in meatball samples is shown in Figure 4 by using the standard rat fat and the standard lard as the comparison. It can be seen that three of fats in meatball sample relatively have the same absorption location (Figure 4). This is the physical and chemical effects of animal fats.

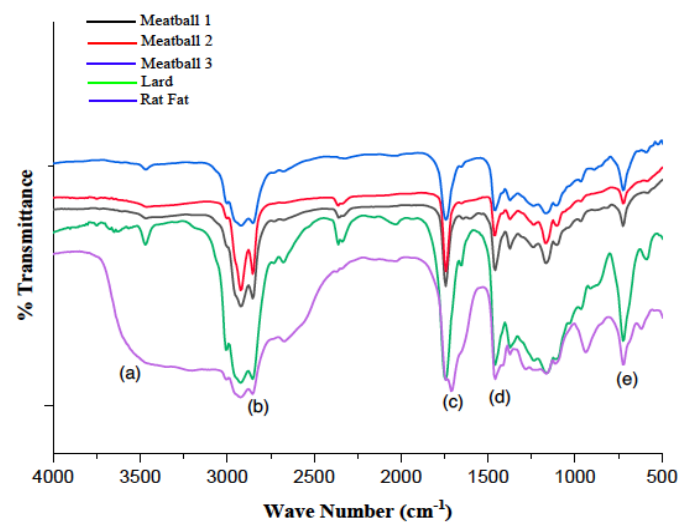

Figure 4. FTIR spectra profile of meatball 1, meatball 2 and meatball 3 with standard lard of pork and rat

As in Figure 4, it is shown that the difference in absorption in the wave number can be indicated by the wide and strong absorption intensity of $3500-3300 \mathrm{~cm}$ (a) in rat fat. The high intensity is due to the stretching vibrations and the combined vibrations that occur in the fat. The weak absorption indicates an overtone of the carbonyl group. The absorption wave number $2924 \mathrm{~cm}$ (b) is the character of the C-H absorption as well as the fatty acid carbon chain. This is approved by the bond wave number $1458 \mathrm{~cm}-1373 \mathrm{~cm}(\mathrm{~d})$. Then the absorption wave numbers 1743 and $1712 \mathrm{~cm}$ (c) are indicated for the specific $\mathrm{C}=\mathrm{O}$ bond of triacyl glycerol. The similarity of the typical uptake of these fatty acids can be seen in animal fat spectra. The distinguishing markers are marked on the absorption wave number of the fingerprint area $1400-700 \mathrm{~cm}(\mathrm{e})$.

However, the absorption at $1743.65 \mathrm{~cm}^{-1}$ is general absorption of ester compounds possessed by animal fat. Therefore, the absorption at that wave number is shown in all spectrums in Figure 4. The characteristic of lard meatball sample obtained is same with the standard lard. There is the typical absorption in the number area wave in $2700-2800 \mathrm{~cm}^{-1}$. The third meatball sample that contains the mixture of rat fat and lard, is shown the accumulated absorption bands of the typical rat fat and fat. This character is seen from the area of wave numbers $1450 \mathrm{~cm}^{-1}$ and $1475 \mathrm{~cm}^{-1}$ with the overlapping absorption bands of the animal fat characters that make up the mixture. 


\section{Conclusion}

Based on the result of the research and discussion, it can be concluded that the highest yield in fat separation by using the Soxhlet. The extraction is carried out at $70^{\circ} \mathrm{C}$ temperature by using $300 \mathrm{~mL}$ of n-hexane solvent. The Infrared Spectroscopy (FTIR) shows the consistency of the typical absorption band profile of each animal fat. The result of FTIR interpretation shows that there is the increasing of the concentration of the mixture of lard and rat fat and the increasing absorption at wave numbers $3371 \mathrm{~cm}^{-1}, 3332 \mathrm{~cm}^{-1}, 2337 \mathrm{~cm}^{-1}$, and $1743 \mathrm{~cm}^{-1}$. The mixture of lard, rat fat, and chicken fat can be classified by the compatible results by using the infrared spectroscopy.

\section{References}

Bernascone G., Gerster H., Hauser H., Stauble H., \& Schneiter E. (1995). Teknologi Kimia Bagian 2, Terjemahan Lienda Handojo. Jakarta: PT Pradnya Paramita.

Buana, D. L., \& Fajriati, I. (2019), Karakterisasi Lemak Sapi dan Lemak Babi dalam Bakso Menggunakan FTIR Spectroscopy, Indonesia Journal of Halal, 2(1), 15-22.

Bustan, M., Djoni, R., Febriyani, \& Pakpahan, H. (2008). Pengaruh Waktu Ekstraksi dan Ukuran Partikel Terhadap Berat Oleoresin Jahe yang Diperoleh dalam Berbagai Jumlah Pelarut Organik (Metanil). Jurnal Teknik Kimia, 4(15), 15-16.

Guntarti, A., \& Prativi, S. R. (2017). Aplikasi Metode Fourier Transform Infrared (FT-IR) Dikombinasikan dengan Kemometrika untuk Analisis Daging Tikus Rumah (Rattus diardi) dalam Bakso Daging Sapi. Jurnal Pharmaciana, 7(2), 133-140.

Hasanah, A. N. U. (2015), Karakterisasi Asam Lemak Sapi dan Asam Lemak Babi Secara Voltmetri Siklik. Skripsi. Universitas Islam Negeri Sunan Kalijaga, Yogyakarta.

Hidayat, N, Dewi, I. A., \& Hardani, D. A., (2013), Ekstraksi Minyak Melati (Jasminum sambac) (Kajian Jenis Pelarut dan Lama Ekstraksi). Jurnal Industri, 4(2), 82-88.

Jaswir I, Mighrani M. E. S., Hasan T. H., \& Said M. Z. M. (2003). Determination of Lard in Mixture of Body Fats of Mutton and Cow by Fourier Transform Infrared Spectroscopy. Journal of Oleo Science, 52(12), 633-638.

Pebriana, R. B, Rohman, A., Lukitaningsih, \& Sudjadi, E. (2017). Pengembangan Spektroskopi FFTIR dalam Kombinasi dengan Chemometrics untuk Analisis Daging Tikus dalam Sosis Dading Sapi Menggunakan Tiga Sistem Ekstraksi Lipid. Internasional Jurnal Properti Pangan, 20, 195-205.

Prabawati, S. Y., \& Fajriati, I. (2018). Analisis Lemak Sapi dan Lemak Babi Menggunakan Gas Chomatography (GC) dan Fourier Transform Infra Red Spectroscopy Second Derivation (FTIR2D) untuk Auntentifikasi Halal. Indonesia Journal of Halal, 1(2), 89-96

Rahmania, H. (2014). Analisis Daging Tikus dalam Bakso Sapi Menggunakan Metode Spektroskopi Inframerah yang Dikombinasikan dengan Kemometrika. Skripsi. Universitas Gajah Mada, Yogyakarta.

Rahmania, H., Sudjadi, \& Rohman, A. (2015). The Employment of FT-IR Spectroscopy in Combination with Chemometrics for Analysis of Rat Meat in Meatball Formulation. Elsevier, Meat Science: 301-305.

Rohman, A., Al'Ikhsan, B. M., Ghazali, Windarsih. A., Irnawati, Riyanto, S., Farahwahida, M. Y. \& Shuhaimi. M. (2020). Review: Comprehensive Review on Application of FTIR Spectroscopy Coupled with Chemometrics for Authentication Analysis of Fats and Oils in the Food Products. Molecules, 25, 5485.

Utami, W. S., Rahayu, I., Nugraha, \& Rochana, A. N. (2017), Fatty Acid Analysis of Lipid Extracted from Rats by Gas Chromatography-Mass Spectrometry Method, The 2nd Annual Applied Science and Engineering Conference (AASEC 2017) IOP Conf. Series: Materials Science and Engineering. 012115 doi:10.1088/1757-899X/288/1/ P I

Vacawati, W. D., Kuswandi, B., \& Wulandari, L. (2013). Deteksi Lemak Babi dan Lemak Ayam Menggunakan Spektoskopi FTIR (Fourier Transform Infra-Red) dan Kemometrik Sebagai Verifikasi Halal. Laporan Penelitian. Universitas Jember.

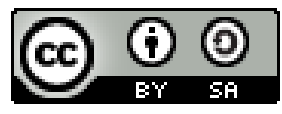

(C) 2021 by Indonesian Journal of Halal Research (IJHAR). Submitted for possible open access publication under the terms and conditions of the Creative Commons Attribution (CC BY SA) license (https://creativecommons.org/licenses/by-sa/4.0/). 